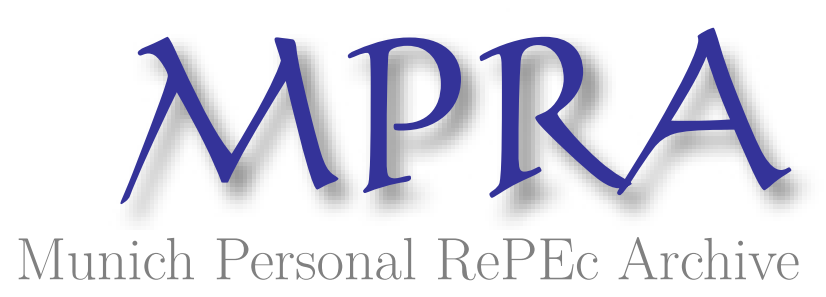

\title{
Impact of IFRS transition on audit and non-audit fees: evidence from small and medium-sized listed companies in Finland.
}

Vieru, Markku and Schadewitz, Hannu

University of Lapland, Turku School of Economics at the University of Turku

2010

Online at https://mpra.ub.uni-muenchen.de/44664/

MPRA Paper No. 44664, posted 01 Mar 2013 11:21 UTC 


\title{
Impact of IFRS transition on audit and non-audit fees: evidence from small and medium-sized listed companies in Finland
}

\begin{abstract}
This study focuses on fees paid to auditors during a major accounting change associated with extra audit risk and work. Specifically, we analyse how a major accounting change from local GAAP to IFRS (International Financial Reporting Standards) affects the audit and non-audit fees paid to auditors. Prior research had evidenced that several auditee-specific properties are associated with audit fees. However, there is lack of specific knowledge on how a major accounting change affects audit and, especially, non-audit fees. Our sample comprises Finnish listed firms that adopted IFRS for the first-time. The Finn-

We are grateful to Authorized Public Accountant (APA) Antti Fredriksson, Pasi Horsmanheimo, Markku Rahiala, Petri Sahlström, Mikko Zerni, and Tiina Visakorpi for discussions, comments, and suggestions. Special thanks are due to APA Pekka Pajamo, who donated his experience and time and helped us to sharpen our views of domestic auditing practise and legislation. We are also grateful for comments by participants at the $31^{\text {st }}$ EAA (European Accounting Association) annual congress in Rotterdam, Netherlands, and the two anonymous referees. We also thank Thomson Financial for providing the stock market data. Markku Vieru (Adjunct Professor at the University of Oulu) would like to thank the Department of Accounting and Finance at the University of Oulu for excellent working support and conditions. Otso Halsti is acknowledged for research assistance. The authors are solely responsible for the final interpretations.
\end{abstract}

MARKKU VIERU, Professor

University of Lapland, Faculty of Business and Tourism • e-mail: markku.vieru@ulapland.fi

HANNU SCHADEWITZ, Professor

Turku School of Economics, Department of Accounting and Finance • e-mail: hannu.schadewitz@tse.fi 
ish data are employed since prior research findings suggest that there are large differences between Finnish accounting standards (FAS) and IFRS anticipating extra audit risk and work at the accounting move. Therefore, it is highly likely that extensive supply for audit and non-audit services during the transition from FAS to IFRS would occur. When taking into account several control variables, in line with prior research, our analyses based on unique, hand-collected data provide evidence that a company with a high FAS-IFRS disparity is associated with more costly non-audit services during the transition phase than one with low disparity. Furthermore, the results reveal that audit fees, where audit markets are more competitive, are not significantly related to the magnitude of IFRS adjustments. Overall, the research findings inform, among other things, audit firms and their clients about the type and the level of costs incurred during a major accounting change.

Keywords: audit supply, non-audit fees, audit fees, IFRS, transition

\section{INTRODUCTION}

For many firms globalization of financial reporting has created a need to prepare their financial statements using the International Financial Reporting Standards (IFRS) issued by the International Accounting Standards Board (IASB) ${ }^{1}$. Consequently, companies listed in the European Union (EU) are required by decision of the European Parliament and Council to prepare consolidated financial statements in accordance with IFRS for years beginning on or after January 1, 2005. For companies the adoption of new accounting standards is likely a huge step, especially if the local accounting standards differ significantly from the global standards. Under these circumstances the need for sufficient resources, training, dedication, communication and preparation by local authorities, managers and auditors is required.

For auditors the complexity of the IFRS transition and the client's potential insufficient preparations can increase uncertainties and risks in their audit assignment. For example, Hoogendoorn (2006) has argued that companies have underestimated the complexities, effects and costs of IFRS (see also Jermakowicz and Gornik-Tomaszewski 2006). In EU countries there is also evidence of limited IFRS transition preparation (PricewaterhouseCoopers 2004a; ICAEW 2004). Also, in Finland the transition to IFRS has resulted in considerable costs for the firms audited and for the auditors themselves (Ministry of Trade and Industry 2003b, 62; KPMG 2006). For example, in order to enhance audit and assurance supply, KPMG Finland established a special IFRS audit team for their customers (KPMG 2009). Furthermore, compared to local GAAP, IFRS may allow for more judgement by management in deciding how they will comply with IFRS (Marden and

1 In addition many other countries have required companies to adopt IFRS. According to Ball (2006), there are almost one hundred countries who have adopted them. Recently, SEC (2007) eliminated the requirement for foreign private issuers who submit financial statements in accordance with IFRS to reconcile their statements to U.S. GAAP. Furthermore, in 2008 the AICPA (American Institute of Certified Public Accountants) voted to add the IASB to the approved list of accounting standards-setting bodies, effectively giving private companies the option to use IFRS. 
Brackney 2009). Recent studies (Street, Gray and Bryant 1999; Street and Bryant 2000; Glaum and Street 2003) have documented significant noncompliance with the disclosure requirements of IFRS in many areas. Hodgdon et al. (2009) show that statutory audit plays an important role in compliance with IFRS. On the other hand, during major accounting changes auditing companies are usually the natural non-audit consultancy service provider for auditees (Patel et al. 2009). Major accounting changes, like the transition from local accounting standards to IFRS, create extra client risk and more time-consuming work for the auditor; both of which are likely to be reflected in audit (audit origin) and non-audit (consultation origin) fees.

This paper looks into the fees paid to statutory auditors associated with the companies in Finland which implement IFRS for the first time. Recent guidelines by Corporate Governance Working Group (2004) enable us to hand-collect the audit and non-audit fee data in order to analyse the audit and non-audit production due to the transition of Finnish companies to IFRS. By focusing on small- and medium-sized listed firms in Finland we shed new insight onto this issue. The sample firms are first-time adopters; therefore it is likely that audit and non-audit fees are affected by the IFRS transition (i.e. so-called supply effect). So far this topic is a mainly unresolved research issue. Typically, non-audit services are positively associated with audit fees (e.g. Simunic 1984; Palmrose 1986). Analyzing audit and non-audit fees is of interest when examining the cost structures of auditing companies, predicting future fees and investigating pricing policies. This information would be useful for auditing companies and their clients regarding the type, the level and the duration of costs incurred during a major accounting change. Although it is known that complexity and risk in general increase fees, how IFRS transition affects audit (audit origin) and non-audit (consultation origin) fees is mainly unknown.

The Finnish data, along with certain background, provide a suitable platform for the study. Previous literature has documented that i) Finnish Accounting Standards (FAS) deviate from IAS (e.g. Kinnunen et al. 2000; Ding et al. 2007), and that ii) the FAS has uniquely national roots - the traditional bookkeeping model is based on the so-called expenditure-revenue theory (e.g. Räty 1992; Kettunen 1993; Pirinen 2005). While the IFRS is characterised to be more principle-based, the FAS can be classified as rule-based, which according to Marden and Brackney (2009) may increase audit risk. Since the institutional setting of Finland resembles a typical Continental European country with concentrated corporate ownership and code law oriented legal system, we suppose that the research findings correspondingly provide insights for other countries as well.

This research is motivated by two gaps in the present literature. First, the extant literature related to IFRS implementation is heavily concentrated on stock market implications. In spite of the widespread adoption of IFRS, there has been much discussion and research questioning the relevance of IFRS (e.g. Leuz and Verrecchia 2001; Leuz 2003; Tarca 2004; Hung and Subramanyam 2007; Horton and Serafeim 2008) and there is only a very limited amount of studies that 
focus on other dimensions related to the transition. Second, of the audit fee studies, there are only a few which investigate how changes in regulatory and disclosure environments affect audit fees and non-audit fees.

Taylor and Simon (1999) have shown that differences in regulatory and disclosure environments affect audit fee differences across countries, but changes in the regulatory and disclosure environment within a single country have rarely been addressed. This is natural since these largescale changes, such as switching from one set of accounting standards to another, seldom occur. Griffin and Lont (2007) have analyzed audit fees in the wake of the Sarbanes-Oxley Act of 2002. Griffin et al. (2009) found that audit fees, but not non-audit fees, were associated with the transition of New Zealand to IFRS. On the contrary, auditor switches are more common, and there are empirical findings that switching costs are related to the legal liability environment (Kallunki, Sahlström and Zerni 2007).

Thus, in order to better understand audit and non-audit fee formation during IFRS transition, more insight is needed to assess whether the complexity of the transition coincides with audit and non-audit fees. The results provide insights, among other things, into whether IFRS financial statements are more costly to audit than FAS financial statements, which would suggest that IFRS transition is associated with audit fees. On the other hand, if the incurred transition costs are mainly associated with non-audit fees rather than audit fees reflecting IFRS start-up and learning, the costs are temporal in nature and will decrease over time (Griffin et al. 2009).

This research has significant implications also for audit companies. Due to the widespread adoption of IFRS, auditors have been forced to evaluate how the transition to the new accounting standards affects the pricing of their services. This contributes to the auditor's evaluation of how complex and time-consuming the actual preparing of the IFRS transition has been in Finland. It is supposed to be reflected in audit and non-audit fees.

The rest of the paper is organized as follows: We discuss audit fee determination based on prior theoretical and empirical research in section 2. Then, based on that discussion, we present two hypotheses. Section 3 displays the methodology applied with special care being given to the research tool applied to quantify the IFRS adjustments. The Finnish institutional setting is displayed together with the data in section 4 . The results from the testing of the hypotheses are reported in section 5. A summary in section 6 concludes the paper.

\section{AUDIT AND NON-AUDIT FEE DETERMINATION AND HYPOTHESES}

\subsection{Audit fee determination}

The economics model of audit pricing suggested by Simunic (1980) and many others (e.g. Simunic and Stein 1996; for identification problem, see Pong and Whittington 1994) implies that an 
auditor's cost function is based on two related components: i) the costs of the audit effort, and ii) the expected cost of the auditor's client-based business risk. The audit effort is needed in order to accumulate enough evidence concerning the quality of the financial statements given. Since the audit fee is the product of unit price and the quantity of audit services, a difference in audit fees can be due to quantity and/or the price component of the fee. Prior literature has indicated several variables that explain the level of audit fees: client size, operational complexity and various aspects of risks. Those variables and model for audit fees paid to statutory auditor will be detailed later in section 3.2.

\subsection{Non-audit fee determination}

The provision of non-audit (consultation origin) services by auditing companies to their audit clients has been a worldwide phenomenon. Non-audit services include such themes as accounting assistance, accounting compilation, ad hoc accounting advice, due diligence, and tax consulting. Decisions regarding these non-audit services are made by a firm's operative management. A handbook published by International Federation of Accountants (IFAC) covers, among others, the code of ethics for professional accountants (IFAC 2008). One of the key themes in that handbook is auditor independence in general and independence e.g. in assurance services. The auditor should always be independent of the client. There have been concerns about how auditors' supply of non-audit services potentially affects their independence (Levitt 2000). As suggested by Hay et al. (2006), a threat to independence can be the result if auditors reduce audit fees as a loss leader in order to obtain consulting work, which would imply a negative relationship between audit and non-audit services.

Prior research has usually found a positive relationship between audit and non-audit fees. Simunic (1984), Palmrose (1986), DeBerg et al. (1991), Davis et al. (1993), and Firth (1997) have all documented a positive relation between audit and non-audit fees, while no relationship is found by Abdel-Khalik (1990), and O'Keefe, et al. (1994). Whisenant et al. (2003) and Hay et al. (2006) empirically document that audit fees and non-audit fees are simultaneously determined. If so, then the significant positive coefficient between audit fees and non-audit fees might be due to misspecification of the model. Whisenant et al. (2003) and Geiger and Rama (2003) evidence a positive relation between audit and non-audit fees using single-equation estimations. However, the relationship between the variables is not evidenced when simultaneous-equation analysis is employed, suggesting that audit fees and non-audit fees are jointly determined. Antle et al. (2006) extend the analyses by adding abnormal accruals into the analyses, since the strength of the economic bond between auditors and their clients may be positively related to the abnormal accruals suggested by e.g. Frankel et al. (2002).

Another body of research examines the implications of the provision of non-audit services 
on an auditor's independence (Reynolds et al. 2004). Generally, the joint supply of these two services can cause positive and/or negative influences on auditing (Frankel et al. 2002). In some countries the provision of consultancy services to audit clients is either outlawed or is strongly discouraged $^{2}$. For example, the Sarbanes-Oxley Act (H.R.3763, U.S. Congress 2002) restricts audit firms from providing certain kinds of management consulting services.

\subsection{Hypotheses}

We posit that auditors assess their audit plan and the expected cost of client business risk in the given institutional and regulatory environments as suggested in the prior literature (Simunic 1980; Taylor and Simon 1999; Cobbin 2002). This means that auditor judgements will be influenced by the characteristics of the auditing environments and the client itself. If regulatory and disclosure environments change creating an impact upon audit pricing components, they should affect audit fees. We believe that not only audit fees but also non-audit fees are under consideration when regulatory and disclosure environments change ${ }^{3}$. Furthermore, we focus on two years: transition year (2004, the year prior to IFRS adoption) and first year of adoption (2005). Limiting our sample to new IFRS adopters and focusing on two years that are critical in IFRS adoption (transition year and adoption year) should inform us of how IFRS adoption is associated to audit and non-audit fees. In other words, our presumption is that the knowledge gap for implementing IFRS in small and medium-sized firms is likely to be substantial which, in turn, is reflected in audit and non-audit fees. Compared to large firms, small and medium-sized firms are less experienced with regard to various international issues in financial accounting e.g. due to their local operations and traditions ${ }^{4}$.

The IFRS transition can be understood as a significant change in regulatory and disclosure environments for the auditor, especially in countries where large differences between domestic GAAP and IFRS exist. Based on previous literature (Kinnunen et al. 2000; Pirinen 2005; Ding et al. 2007), the transition from FAS to IFRS is considered to be a major accounting event which is assumed to affect audit and non-audit fees. Among others, IFRS calls for more judgment by management when deciding how they will comply with IFRS (Marden and Brackney 2009). Also the disclosure requirements of IFRS are much more detailed compared to FAS.

However, not only the increase in regulation and disclosure requirements but also the increase in the complexity of the transition plus the possible lack of preparation (e.g. by Hoogen-

2 In Finland, the statutory auditor is allowed to consult with IFRS-related issues. This activity has also been common since IFRS-related consulting is often mentioned when information about origin of the non-audit fees have been provided. Other frequently mentioned activities are consultations related to corporate income taxation.

3 Mandatory transition should not cause major changes to firms' reporting incentives. For example, Wu (2008) highlighted that in order to minimize the risk of biased conclusions reporting incentives should be as constant as possible.

4 see e.g. Räty (1992), Salmi (1996), and Pirinen (2005). 
doorn 2006; Jermakowicz and Gornik-Tomaszewski 2006; Ministry of Trade and Industry 2003a) create extra risk and work for auditors. In the spirit of Palmrose (1986), companies may lack the suitable accounting and information technology to prepare financial statements that comply with the IFRS accounting requirements, which consequently may act as a signal for the auditor to change to a more intensive, more costly audit programme. Also, Ball $(2006,34)$ has pointed out that in the current IFRS enforcement system there has only been limited success fully implementing the set of standards. Although there have been discussions claiming that the IFRS transition is not fully implemented in practice, from the beginning of the first IFRS financial statements there has also been discussion about the extra work load required ${ }^{5}$. Consequently, the more FAS and IFRS financial statement figures deviate from each other in transaction reconciliation reports, the higher the audit fees. Thus the hypothesis is:

$\mathrm{H} 1$ : There is a positive relation between audit (audit origin) fees and the degree of IFRS adjustments.

Our second hypothesis is related to non-audit (consultation origin) fees. IFRS transition is a major accounting change and affects firms' financial reports in several ways. Since financial statements are remarkably different (especially disclosure requirements) under the IFRS regime compared to the FAS regime, the IFRS regime calls for different preparatory work compared to the FAS regime. It could well be that especially this preparatory work requires a consultation type of auditor involvement that, in turn, is reflected in non-audit fees.

When the IFRS transition is considered as a major accounting event, it calls for preparation, learning and pre-reporting of its impact upon financial accounts (Committee of European Securities Regulators 2003a). In practise, auditors are usually the most natural IFRS advisors and consultants for a company (Jermakowicz and Gornik-Tomaszewski 2006). Indeed, in many annual reports it is explicitly written, among other things, that part of the non-audit fees is based on IFRS transition consultation. Firth (2002) found that non-audit fees were associated with a lower incidence of audit qualifications or modifications. Sharma and Sidhu (2001), however, concluded that large non-audit fees to total fees undermine auditor independence when auditors have a tendency to not issue a going concern qualification to clients. Second, a lack of competition in the IFRS transition market for non-audit services can result in a positive relationship between audit and non-audit fees (Solomon 1990). If there are only few IFRS specialists available, and the common understanding within companies about the IFRS transition requirements is poor (Jermakowitz and Gornik-Tomaszewski 2006), it is tempting to charge extra fees from the

5 Pricing effect is also associated with the competition in audit market. Our discussions with Finnish authorised public accountant professionals (Fredriksson 2009; Pajamo 2009) support the view that the competition in Finnish auditing markets was hard during 2003-2006 which may decrease pricing consequences. 
clients ${ }^{6}$. Consequently, the more FAS and IFRS financial statement figures deviate from each other in transaction reconciliation reports, the greater the difference in non-audit fees. Thus the second hypothesis is:

$\mathrm{H} 2$ : There is a positive relation between non-audit (consultation origin) fees and the degree of IFRS adjustments.

In the empirical part of the study the hypotheses are tested. The tests provide insights into whether auditors experience the IFRS transition as a costly affair. On the other hand, if non-audit fees (but not audit fees) are associated with the deviation between FAS and IFRS in transaction reconciliation reports, in line with Griffin et al. (2009) it suggests IFRS start-up and learning costs are temporal in nature and transition-specific costs are likely to decrease over time.

In the following section we present our research methodology. First, we demonstrate the magnitude of the IFRS adjustments using the analyses of comparability. Second, we provide a model to study whether the amount of IFRS adjustments is actually related to an increase in audit and non-audit fees.

\section{METHODOLOGY}

In this section we introduce a measure for the magnitude of IFRS adjustments using analyses of comparability. This measure is needed in order to recognise and classify material disparity between FAS and IFRS in a structured way. Secondly, we present regression models for audit and non-audit fees which control and take into account several variables frequently employed in prior research.

\subsection{Magnitude and nature of IFRS adjustments}

In previous studies the degree of accounting adjustments between the two accounting standards has been measured using an analysis of comparability. The index of comparability $(C l)$ has been frequently used to identify and quantify accounting adjustments (e.g. Ucieda Blanco and García Osma 2004; Street et al. 2000; Adams et al. 1999). In this study, the magnitude of IFRS adjustments is based on an index of comparability calculated using four indicator variables: two of them are based on an income statement and the other two on a balance sheet. One of the benefits of our focus is that the items and their contents are specifically defined for each firm individually. Our measures are also important economic indicators of the firms' performance and their financing for investors and other stakeholders (Penman 2001). The correctness of the selected items, in

6 According the practising APA professional (Pajamo 2009), the audit firms were proactive during the IFRS transition and adoption time in order to inform their current and potential clients about the IFRS services available. 
turn, is an important issue also for auditors. Differences between FAS and IFRS-based income statement and balance sheet variables might be reflected also in disclosures. We acknowledge that our measure of comparability does not directly capture potential differences in disclosures between FAS and IFRS. We will discuss this issue further in section 5 (Results).

Indicator variables based on an income statement are: i) earnings before interests and taxes, $E B I T$ (Eq. (1)), and ii) net income, NI (Eq. (2)). They are constructed in the following way:

$$
\begin{aligned}
& \text { (1) } C I_{E B I T}=\left(\frac{E B I T_{I F R S}-E B I T_{F A S}}{E Q_{F A S}}\right) \\
& \text { (2) } C I_{N I}=\left(\frac{\left(N I_{I F R S}-N I_{F A S}\right)-\left(E B I T_{I F R S}-E B I T_{F A S}\right)}{E Q_{F A S}}\right)
\end{aligned}
$$

Eq. (1) measures the cumulative IFRS adjustments for the underlying company presented in reconciliations of the income statement down to the EBIT level scaled by book value of equity. The numerator consists of the IFRS adjustments related e.g. to revenue recognition, share-based payments, employee benefits, research and development costs, lease arrangements, goodwill amortization, and goodwill and other asset impairments. Positive (or negative) difference indicates that the IFRS adjustments as a whole have increased (decreased) the EBIT of the company. Eq. (2) measures the cumulative IFRS adjustments between the EBIT level and the NI level of the income statement scaled by book value of equity. In order to avoid counting IFRS adjustments in the income statement twice, Eq. (2) is constructed so that the IFRS adjustments in EBIT (in Eq. 1) are subtracted. The numerator consists of the IFRS adjustments related e.g. to financial instruments and deferred taxes.

The indicator variables based on the balance sheet are equity capital, EQ (Eq. (3)) and total debt, DEBT (Eq. (4)). Eq. (3) measures the cumulative IFRS adjustments for the underlying company presented in reconciliation of the book equity $(E Q)$ scaled by book value of equity. The numerator consists of the IFRS adjustments related to e.g. profit from current and previous years, changes in revaluation reserves, pension liabilities, and costs related to stock issues. Positive (or negative) difference indicates that the IFRS adjustments as a whole have increased (decreased) book equity, $E Q$. Eq. (4) measures the cumulative IFRS adjustments on liabilities (DEBT) scaled by book value of equity. The numerator consists of the IFRS adjustments related e.g. tax liabilities, pension liabilities, and liabilities related to lease agreements. These indicator variables are calculated in the following way:

(3) $C I_{E Q}=\left(\frac{E Q_{I F R S}-E Q_{F A S}}{E Q_{F A S}}\right)$ 
(4) $C I_{D E B T}=\left(\frac{D E B T_{I F R S}-D E B T_{F A S}}{E Q_{F A S}}\right)$

The use of equity capital is unlikely to cause problems related to small and unstable denominators (see e.g. Ucieda Blanco and García Osma 2004; Rees 1995, 94). The comparability score metric is constructed from two income statement-based indicator variables and from two balance sheet-based indicator variables $\left(C I_{E B I T}, C I_{N I}, C I_{E Q}\right.$ and $\left.C I_{D E B T}\right)$ presented above. Since it is assumed that the IFRS adjustments per se are relevant for fees paid to the statutory auditor, absolute values are thus used assuming that both negative and positive adjustments have equal consequences for fees. The sample firms are classified into IFRS adjustments deciles based on each indicator variable. Each decile classification $\left(D C I_{E B I T}, D C I_{N I \prime} D C I_{E Q,}\right.$ and $\left.D C I_{D E B T}\right)$ takes on a value of zero for the smallest decile and nine for the largest.

An aggregated measure of comparability is achieved when the decile classification values for a single company are added together. This procedure returns a maximum value of 36 for companies in which IFRS adjustments have scored in the highest decile (i.e. four times nine) in each IFRS adjustment indicator variable and returns a minimum value of zero for companies whose IFRS adjustments have scored in the lowest decile (i.e. four times zero) in each IFRS adjustment indicator variable. Finally, the obtained figure is scaled to a range between zero and one resulting in our adjustments comparability score $(A D /)$. Eq. (5) below summarizes the computation:

$$
A D J=\frac{D C I_{E B I T}+D C I_{N I}+D C I_{E Q}+D C I_{D E B T}}{36}
$$

The constructed adjustments comparability score $(A D /)$ for a company having the lowest IFRS adjustments for an income statement and balance sheet is zero, whereas a company having the largest IFRS adjustments $A D$ J is one. The use of a constructed comparability score metric has certain advantages over the original variables. Firstly, it aggregates the IFRS adjustments from four different financial statement levels to a single variable. Auditing theory does not inform us how each separate $\mathrm{Cl}$ affects audit and non-audit fees. Despite that some information is lost after aggregating separate $D C /$ s into $A D$ J, the aggregation may, on the other hand, reduce noise. Secondly, the use of scaled decile ranks instead of the original variables provides an efficient tool for taking care of possible outliers associated with extreme values. The implicit assumption is that each indicator variable $(D C / \mathrm{s})$ has an equal and additive effect on fees paid to the statutory auditor. We are aware that this assumption simplifies the setting since audit risk and audit effort related to IFRS adjustments on income statement and balance sheet items may vary. For example, some IFRS adjustments can be classified for routine adjustments and some adjustments need extra work and judgement. We will come back to this issue in our robustness analyses in section 5.3.2. 
In order to gain additional insight (Corbin and Strauss 2008) and supplement the methods above regarding audit and non-audit fees in the Finnish context, we also performed two interviews with two professional Authorized Public Accountants (APAs) (Fredriksson 2009; Pajamo 2009). The interview with APA Fredriksson was a theme interview focusing on audit and non-audit fee levels, their development, and their potential interaction in Finland. Afterwards APA Fredriksson supplied some additional information regarding the topic under discussion. The interview with APA Pajamo was semi-structured; more than two weeks before the interview we sent the whole manuscript (version 16 Sep 2009) and the cover letter to him. In the cover letter we summarize the major findings in the paper and stated a few questions based on those results and the interview with APA Fredriksson. We also proposed a few general questions regarding professional audit issues, such as the role of IFAC recommendations in Finnish audit practises. The agenda in the interview with APA Pajamo was as follows: First we handled six broader issues related to the paper, also covering the questions in the cover letter. Second we went through the paper itself and discussed some of its details. The interviewer made notes throughout the session. It should be noted here that both of the interviewees have read this paper and accepted the presented information based on these interviews. The opinions presented in the interviews are the interviewees' own personal opinions and do not necessarily represent the views of their employers.

\subsection{Models for audit and non-audit fees paid to the statutory auditor}

Here we derive models for audit and non-audit fees paid to the statutory auditor in order to analyse whether the IFRS adjustments (measured by $A D$ ) ) are related to those fees (Eqs (6) and (7) below). As noted by Whisenant et al. (2003), it is possible to estimate these two equations separately using a single-equation estimation technique if audit and non-audit fees are determined independently. ${ }^{7}$ In line with prior literature, detailed below, several control variables for client size, operational complexity and various aspects of risks are also included in the models.

Previous studies have frequently indicated that the most important variable in explaining the level of audit fees is the size of the auditee. In these studies the company size is assumed to be related to the need for more time, resources and effort in preparing, analyzing and testing the company information before the issuance of audit opinion (e.g. Simunic 1980; Palmrose 1986; Davis et al. 1993; Bell et al. 2001; Chung and Narasimhan 2002; Cobbin 2002). In Cobbin's (2002) survey of auditing literature, the size variable is always reported as a significant and positive determinant of audit fees. The natural logarithm of total assets is frequently used since, for example, economies of scale reduce audit work. Also, it is likely that non-audit services are higher for large-sized companies. Our measure for size is the logarithm of total assets $\ln (S I Z E)$. 
Also, the complexity of the auditee increases the need to spend time and conduct larger and deeper testing procedures and analyses. There are country-specific differences in the level of financial accounting information disclosure (Hope 2003). Since the auditor has to examine and become familiar with both financial reporting systems and financial disclosures, it is reasonable to expect that more fees are required due to extensive reporting (i.e. high complexity).

The results of many earlier studies support the idea that the client's operational complexity is a significant variable in determining the level of audit fees (Simunic 1980; Niemi 2002; Whisenant et al. 2003; Nikkinen and Sahlström 2005; Joshi and Al-Bastaki 2000) and non-audit fees (Palmrose 1986; Solomon 1990; Whisenant et al. 2003). The complexity can be related to asset structure and business operations. Simunic (1980) and Francis and Simon (1987) suggest that receivables and inventories require subjective judgement and consume more time in determining their values and, accordingly, are difficult and risky to audit. Complexity increases also if the company has numerous subsidiaries and other entities within the group (Simunic 1980). The location of subsidiaries can also make a difference. Multinationals with more detailed reporting and added complexity require increased audit effort because of the greater need for corporate governance and differences in accounting standards and practises. Ezzamel et al. (1996) and Niemi (2005), among others, have hypothesised and evidenced that audit fees are affected by foreign location of subsidiaries. We control operational complexity by employing two commonly used variables: i) the ratio of the sum of inventories and accounts receivable to total assets $(I N V R E C)$, and ii) the square root of the number of subsidiaries (SQ(SUBS)).

The risk component is related to the auditor's potential future loss due to the possibility of e.g. litigation or a client's failure. Audit risk can be defined as the risk that financial statements may be materially misstated after the audit is completed and an unqualified opinion be issued (Arens and Loebbecke 1994). Audit effort and audit risk are related since auditors address some forms of business risk by increasing audit effort, which in turn causes higher audit fees (e.g. Pratt and Stice 1994; Bell et al. 2001). This implies that the higher the anticipated audit risk the more numerous the audit tests perceived as necessary. In addition, a higher fee is required to compensate for the greater anticipated risk of audit failure. Audit risk is also an important element in determining the level of audit fees (e.g. Simunic and Stein 1996; Pratt and Stice 1994; Bell et al. 2001). Risk can arise in different ways (see e.g. Firth 1997, 513). Poor profitability and growth opportunities (e.g. Whisenant et al. 2003; Nikkinen and Sahlström 2005) can be related to risk. Our measure for profitability is $R O E$. We measure growth opportunities by the ratio of market value to book value of equity $(M B)$.

Also, the following risk categories can affect audit fees: market risk (e.g. Nikkinen and Sahlström 2005), financial risk (e.g. Bell et al. 2001; Niemi 2002) and liquidity risk (e.g. Nikkinen and Sahlström 2005; Camaran 2005). BR is our market risk variable measured by equity beta. It 
is estimated by Sharpe's (1964) market model using daily stock and OMX25 index returns over a one-year period before the end of the fiscal year. Our financial risk variable is FLEV computed as the debt to equity ratio. We measure liquidity risk by quick ratio $Q R$ (ratio of current assets less inventories to current liabilities).

Finally, systematic differences in audit fees may exist among the different audit firms. E.g. Moizer (1997) reported that Price Waterhouse charges higher fees in many countries. In line with Niemi (2005), to control the possible pricing or effort differences between PricewaterhouseCoopers (PWC) and the other audit firms, an indicator variable ( $P W C)$ was added to the audit model. In audit research PwC is normally not singled out, but what is contrasted is Big Four versus nonBig Four audit firms. In the sample, however, there are hardly any non-Big Four audit firms, motivating the $P W C$ dummy instead of indicator variables for Big Four audit firms.

The magnitude of the IFRS adjustments comparability score $(A D /)$ is the variable of interest in the following cross-sectional regression model for audit fees:

$$
\begin{aligned}
\ln \left(A U_{i t}\right)= & a_{0}+a_{1} \ln \left(N A U_{i t}\right)+a_{2} A D J_{i t}+a_{3} \ln \left(S I Z E_{i t}\right)+a_{4} I N V R E C_{i t}+a_{5} S Q\left(S U B S_{i t}\right)+ \\
& a_{6} R O E_{i t}+a_{7} M B_{i t}+a_{8} B R_{i t}+a_{9} F L E V_{i t}+a_{10} Q R_{i t}+a_{11} P W C_{i t}+v_{i t}
\end{aligned}
$$

If the regression results are consistent with the first hypothesis, then they would produce a positive and statistically significant parameter value for $a_{2}$ in the regression model (6).

To examine the second hypothesis, we constructed a non-audit fee (NAU) model with control variables for client size, operational complexity and various aspects of risk. Regarding new financing, it is possible that new equity or debt issues can affect the non-audit fees (e.g. Whisenant et al. 2003). Therefore we add a variable indicating whether the company has issued equity or long-term debt in either the current year or subsequent fiscal year. Again, the magnitude of the IFRS adjustments comparability score, $A D$ J, the variable of interest in the following cross-sectional regression model:

$$
\begin{gathered}
\ln \left(N A U_{i t}\right)=b_{0}+b_{1} \ln \left(A U_{i t}\right)+b_{2} A D J_{i t}+b_{3} \ln \left(S I Z E_{i t}\right)+b_{4} I N V R E C_{i t}+b_{5} S Q\left(S U B S_{i t}\right)+b_{6} R O E_{i t}+ \\
b_{7} M B_{i t}+b_{8} B R_{i t}+b_{9} F L E V_{i t}+b_{10} Q R_{i t}+b_{11} D I S S U E_{i t}+w_{i t}
\end{gathered}
$$

The other independent variables are the same as in model (6) except that the non-audit fee variable is replaced by an audit fee variable and the last indicatory variable is replaced by a new finance indicator variable DISSUE. DISSUE receives value one if the company has issued equity or long-term debt in either the current year or subsequent fiscal year (zero otherwise). If the regression results are consistent with the second hypothesis, they would produce a positive and statistically significant parameter value for $b_{2}$ in the regression model (7). 


\section{THE INSTITUTIONAL FRAMEWORK AND DATA}

\subsection{The auditing and enforcement of IFRS financial statements in Finland}

For the time being, the enforcement of the IFRS financial statements in the EU relies heavily on external auditors and national enforcement systems (Haller 2002, 178). In Finland, during the sample years, auditing was stipulated in the Auditing Act (936/28.10.1994) which became valid when Finland joined the EU in the beginning of 1995. As a member state of the EU, Finland has the obligation to ensure that the Finnish auditing regulations comply with the Directives of the European Commission. The Auditing Act defines the purpose and the scope of auditing. AU fees comprise fees due to statutory audit. ${ }^{8}$

Statutory audit covers an examination of the accounting records, financial statements, the report of the Board of Directors, and also the administration of the client corporation (Section 17). As part of the EU and internationalization, changes were made to the Audit Act in 2007 (459/2007). For example, an auditor is no longer required by law to provide an opinion on the board of directors and managing director discharge from liability or the suggested profit distribution. However, the auditor must report on these two areas if the audit work suggests that a qualified audit opinion should be issued. Furthermore, a company (Annual General Meeting, the Board of Directors) can request such an opinion, and the auditor is authorized to supply that opinion.

Audits of parent companies in Finland also cover consolidated financial statements. The audits result in a statement of whether Members of the Board of Directors and the Managing Director can be discharged from liability for the financial period audited by the auditor. According to the Act in force during our research period 2004-2005 (Section 19), auditors must also give an opinion on: i) whether the audited financial statements comply with the prevailing legislation and generally accepted accounting practises, ii) whether the financial statements give a true and fair view of the clients performance and financial position, and iii) whether the use of profit and the distribution of other unrestricted equity is in compliance with the Limited Liability Companies Act. In addition of the Auditing Act, certified auditors must also follow the recommendations of the Finnish Institute of Authorized Public Accountants (these recommendations are consistent with the International Standards on Auditing (ISA)). This was the situation also during our research period 2004-2005. A recently published Finnish translation of ISA provides even more detailed guidance for audits. Finland has a two-tier system of certification of public accountants. For all

8 The auditor (incumbent auditor nominated by the General Meeting) presents the audit report to listed firm's shareholders at the General Meeting. According the Companies Act (Chapter 6: Management and representation of the company, Section 2: General duties of the Board of Directors, Airaksinen et al. 2007) The Board of Directors is responsible, among other things, for the appropriate arrangements of the control of the company's accounts and finance. This duty, amongst other responsibilities of the Board, is audited by the statutory auditor of the company. 
listed companies, as well as the largest companies, the Auditing Act (Section 12) requires "firsttier" auditors approved by the Central Chamber of Commerce (Authorized Public Accountant, APA) in its certification exam.

The auditor's liability is defined in the Auditing Act (Section 44). In addition to the client losses arising from negligent performance by the auditor in an audit, the auditor may also be held responsible for losses suffered by third parties when the auditor has failed to follow the prevailing laws (e.g. Accounting Act, Company Law and Audit Act) or company by-laws (Finnish Generally Accepted Auditing Standards (Finnish GAAS) provided by the Finnish Institute of Authorised Public Accountants). Niemi $(2002,40 ; 2005,307)$ has pointed out several features in the legal system which mitigate auditor litigation to clients and third parties. For example, legal awards are limited to the plaintiff's actual loss, thus being without punitive aspect. Also, class actions lawsuits are not possible. On the other hand, in Finland there is no upper limit for compensation for damages. Therefore audit risk insurance is especially useful in Finland.

In Finland the Financial Supervision Authority (FIN-FSA) carries total responsibility for the overall IFRS supervision they oversee (comprising chiefly of listed companies, insurance companies, and financial institutions). Auditors have a responsibility to the shareholders of the firms they audit. FIN-FSA supervision covers all companies that are liable to comply with the IFRS. Only companies which are required to adhere to the IFRS standards fall within the scope of the supervision. The IAS Supervision Working Group (Ministry of Trade and Industry 2003a) has described the IFRS enforcement system (in Finnish). The material to be checked is based on random sampling. For other companies the external control remains with a statutory auditor. The FIN-FSA's IFRS supervision covers documents subject to the regular reporting obligations in accordance with securities market legislation. In addition, the FIN-FSA can ask for an opinion from the Finnish Accounting Board on the application of the IFRS. If misstatements are found, appropriate actions are required. The most important action is the right to require a correction in which case the supervisor demands a company make public a defect or demands a restatement of financial information. Regardless of a Finnish Financial Supervision Authority's (2005) report concerning the differences in the quality of IFRS financial statements, restatements have not been recorded during the sample years. In FIN-FSA's investigation of an IFRS transition a public reprimand or a public warning can also be used. For uniform enforcement FIN-FSA co-operates with CESR (Committee of European Securities Regulators 2003b).

\subsection{The transition from FAS to IFRS}

A company preparing its first IFRS financial statements for 31 December 2005 has an adoption

date of 1 January 2005 (PricewaterhouseCoopers 2004b). The transition date to IFRS for this company is 1 January 2004. IFRS 1 requires companies retrospectively implement and publish 
their 2004 annual financial statements according to the IFRS standards. Companies are also required to report comparison figures, according to the FAS, as an analysis of the differences between the IFRS and FAS figures. Accordingly, listed Finnish companies are required to provide their unaudited reviews in order to assess the preliminary main impacts of the transition to IFRS. These reviews are based on the financial information for 2004, which was originally reported according to FAS. Thus, due to transition standard IFRS 1, the transition period has unique features which are in part relics from the FAS past.

Because the transition from one accounting standard to another is a demanding and complicated issue, it should be well communicated to the firms' various stakeholders. ${ }^{9}$ Follow-up reports have shown that the quality of IFRS transition communication, as well as the quality of the IFRS financial statements for 2005, varied among the recent IFRS first-time adopters. According to the Finnish Financial Supervision Authority (2005), two-thirds of the companies on the main list of the Helsinki Stock Exchange handled their IFRS transition communication well, but the communication of most of the I-list companies was rated as weak. Schadewitz and Vieru (2006) show that the IFRS communication before the transition in Finland was mostly narrative and that quantitative information was scantly provided. However, Miihkinen (2008) discovered that authoritative disclosure recommendations had a robust effect on improving the firms' reporting during IFRS transition in Finland.

In addition, according to the Finnish Financial Supervision Authority (2006), the quality of the listed companies' 2005 IFRS financial statements varied. FIN-FSA concluded that some financial statements were properly prepared, but many financial reports of lower quality were also encountered and still needed developing. Also, in KPMG's $(2006,4)$ report it is admitted that the estimates and adjustments produced were more rough than usual for Finland, resulting in the need for further improvement work to be done in the following years. These kinds of findings related to Nobes's (2006) and Alexander's (2006) critique concerning the common interpretations and applications of IFRS also create challenges for the auditors' work. Furthermore, there are various adjustments that firms need to execute when switching their reporting to be in line with the IFRS (see e.g. KPMG 2002; 2003). Overall, these findings suggest that in Finland the transition to IFRS is a significant project for listed firms fuelling especially an increased advisory (NAU) supply.

CESR (Committee of European Securities Regulators 2003a) has prepared recommendations for listed companies which concern providing markets with appropriate and useful information during the transition phase. This information is crucial, especially when, as in Finland, the local

9 During the transition and adoption period 2004-2006 the development of IFRS standards has been somewhat frozen by IABS on purpose in order to support the transition and adoption of IFRS. Since 2007 the development of standards has been again vivid. 
GAAP deviates greatly from the IFRS. CESR (2003a) recommends (in para. 22) that as soon as a company can quantify the impact of the change resulting from IFRS on its financial statements, in a sufficiently reliable manner, it should be encouraged to disclose the relevant quantified information. Potential shortcomings in this transition period of communication could create severe information asymmetry problems for investors and other stakeholders concerning the proper analysis of companies and, in turn, could cause capital misallocations and other biased decisions.

\subsection{The sample}

The hypotheses are tested using data from Finland. The fee variables (audit fees paid to statutory auditor, AU, and non-audit fees paid to statutory auditor, NAU) are based on the companies' annual reports. The adjustments comparability score (ADJ) is based on IFRS adjustments found from the companies' transition reconciliation reports available on OMHEX's homepage (http://www. omxgroup.com). Other variables used are based on the information available in the Thomson Financial database and the firms' annual reports. The sample size was decreased for several reasons (see table 1 below). Firstly, there were thirteen early IFRS adopters. Secondly, there are ten firms which are excluded from the sample due to large restructuring activities (e.g. mergers, spinoffs, carve-outs), a recent listing, or the fact that the company belongs to the financial services or insurance industry. Restructuring activities and IPOs cause short and heterogeneous financial time series. Banks, financial services and insurance companies are excluded since the structure of their financial statement information differs considerably from other firms. The IFRS adjustments are collected from the reconciliations of the sample firms. The reconciliation for profit and loss statements covers the fiscal year that ends during year 2004 and reconciliations of equity are based on the corresponding closing balance sheets.

According to corporate governance recommendation (Corporate Governance Working Group 2004) No. 54, Finnish listed companies shall report the fees of the external auditor during the financial year. If the external auditor has been paid fees for non-audit services, such fees shall be

\section{TABLE 1. Sample selection.}

\begin{tabular}{|lrr} 
Listed companies & 133 & $100.00 \%$ \\
$\quad$ Early IFRS adopters & 13 & $9.77 \%$ \\
\hline Recent IFRS adopters & 120 & $90.23 \%$ \\
$\quad$ Excluded for various reasons (e.g. restructuring, IPO, industry) & 10 & $7.52 \%$ \\
Missing audit or non-audit fee data & 26 & $19.55 \%$ \\
Missing observations in Datastream & 11 & $8.27 \%$ \\
\hline Final Sample & 73 & $54.89 \%$
\end{tabular}


reported separately. Usually, companies have provided both audit fees and non-audit fees. Fees were incompletely reported by 26 firms, and for 11 companies the requested information is not available in the Thomson Financial database. Thus, the final sample consists of 73 firms that have a complete set of the information requested. The selection process is described in Table 1. Since the data are based on the years 2004 and 2005, the number of firm-years is 146. After our research period, there have been further specifications for non-audit fees in the Finnish Accounting Statute. Accordingly, non-audit fees for tax advisory, audit-related advisory, and other advisory services should be reported separately. Also statutory audit fees should be reported separately as was the case in our research period.

\section{RESULTS}

\subsection{The descriptive statistics of the IFRS adjustments}

Table 2 shows the descriptive statistics of the index of comparability $(\mathrm{Cl})$ for earnings before interest and taxes $\left(C I_{E B I T}\right)$, net income $\left(C I_{N I}\right)$, equity capital $\left(C I_{E Q}\right)$ and total debt $\left(C I_{D E B T}\right)$. The descriptive statistics show that EBIT calculated according to IFRS is on average higher compared to EBIT calculated according to FAS. This is indicated by the mean value for the index of comparability which results in a positive value (0.039). Also, the debt-to-equity ratio is on average higher (0.084) when calculated according to IFRS rather than FAS. For other indicators the average effects of accounting standards are minor.

TABLE 2. The descriptive statistics of the index of comparability measures.

\begin{tabular}{lcrcrrrrr} 
Variable & $\mathrm{N}$ & Mean & Std & Min & Q1 & Median & Q3 & Max \\
\hline$C I_{E B I T}$ & 73 & $\mathbf{0 . 0 3 9}$ & $\mathbf{0 . 1 3 7}$ & $-\mathbf{0 . 5 6 5}$ & $\mathbf{0 . 0 0 7}$ & $\mathbf{0 . 0 2 7}$ & $\mathbf{0 . 0 4 5}$ & $\mathbf{0 . 6 7 3}$ \\
$C I_{N I}$ & 73 & $\mathbf{0 . 0 0 4}$ & $\mathbf{0 . 0 7 8}$ & $-\mathbf{0 . 1 2 3}$ & $\mathbf{- 0 . 0 1 0}$ & $\mathbf{- 0 . 0 0 2}$ & $\mathbf{0 . 0 0 5}$ & $\mathbf{0 . 6 0 5}$ \\
$C I_{E Q}$ & 73 & $-\mathbf{0 . 0 1 1}$ & $\mathbf{0 . 1 0 4}$ & $-\mathbf{0 . 3 4 2}$ & $-\mathbf{0 . 0 4 8}$ & $\mathbf{0 . 0 0 0}$ & $\mathbf{0 . 0 3 6}$ & $\mathbf{0 . 2 7 6}$ \\
$C I_{D E B T}$ & 73 & $\mathbf{0 . 0 8 4}$ & $\mathbf{0 . 1 6 6}$ & $-\mathbf{0 . 2 1 7}$ & $\mathbf{0 . 0 0 7}$ & $\mathbf{0 . 0 4 2}$ & $\mathbf{0 . 1 1 8}$ & $\mathbf{1 . 0 3 8}$
\end{tabular}

Note: the index of comparability $(\mathrm{CI})$ for indicator variables was calculated according to Eqs (1)-(4). (see section 3.1.).

Table 3 shows the number of material and non-material adjustments for each indicator variable. We have set the materiality threshold in two different bands: a 0.05 band and a 0.10 band. If the index of comparability is between -0.05 and 0.05 , we classify the adjustment as having no material impact on our indicator variables; we consider it material otherwise. Likewise, when we set the threshold at 0.10 , all adjustments with an index of comparability equal to or lower than -0.10 and larger or equal to 0.10 are considered material, and non-material otherwise. 
This is a methodology previously used e.g. by Street et al. (2000) and Ucieda Blanco and García Osma (2004).

Table 3 suggests that material adjustments seem to be quite frequent on balance sheet variables (measured by $C I_{E Q}$ and $C I_{D E B T}$, see Eq. 3 and 4), whereas in the income statement variables (measured by $C I_{E B I T}$ and $C I_{N I}$, see Eq. 1 and 2) a somewhat lower frequency was reconciled. Usually, the adjustments to EBIT are positive, whereas the IFRS adjustments in reconciliations between $\mathrm{NI}$ and $E B I T$ (measured by $\mathrm{CI}_{\mathrm{N}}$, see Eq. 2) are quite equally distributed. Material adjustments on debt usually have a positive sign (i.e. more debt). The number of positive adjustments is 32 and the number of negative adjustments is 4 . The number of material adjustments on equity is quite balanced, 15 being positive and 18 negative. The analysis indicates also that $55 \%$ of companies (40 of 73) have had non-material adjustments in equity capital. Ucieda Blanco and García Osma (2004) reported equity capital adjustments related to Form 20-F reconciliations (p. 20). Comparison of the findings reveals that, in this study, the cases with non-material IFRS adjustments to equity capital between FAS and IFRS are more infrequent than the corresponding US GAAP adjustments (being 76\%, based on the last row from Table 6 in the Ucieda Blanco and García Osma (2004) study) between IAS and US GAAP. ${ }^{10}$

TABLE 3. The frequency and proportion distributions of the index of comparability measures $(N=73)$.

\begin{tabular}{|c|c|c|c|c|c|c|c|c|}
\hline \multirow[b]{3}{*}{ Index value } & \multicolumn{8}{|c|}{ Indicator variable } \\
\hline & \multicolumn{4}{|c|}{ Frequency (\#) } & \multicolumn{4}{|c|}{ Proportion (\%) } \\
\hline & $C I_{E B I T}$ & $C I_{N I}$ & $C I_{E Q}$ & $C I_{D E B T}$ & $C I_{E B I T}$ & $C I_{N I}$ & $C I_{E Q}$ & $C I_{D E B T}$ \\
\hline$\leq-0.10$ & 2 & 1 & 9 & 4 & $3 \%$ & $1 \%$ & $12 \%$ & $5 \%$ \\
\hline$-0.099--0.050$ & $\mathbf{0}$ & 4 & 9 & $\mathbf{0}$ & $0 \%$ & $5 \%$ & $12 \%$ & $0 \%$ \\
\hline$-0.049-0.049$ & 53 & 64 & 40 & 37 & $73 \%$ & $88 \%$ & $55 \%$ & $51 \%$ \\
\hline $0.050-0.099$ & 12 & 2 & 11 & 12 & $16 \%$ & $3 \%$ & $15 \%$ & $16 \%$ \\
\hline$\geq 0.10$ & 6 & 2 & 4 & 20 & $8 \%$ & $3 \%$ & $5 \%$ & $27 \%$ \\
\hline \multicolumn{9}{|l|}{ Range: } \\
\hline Highest value & 0.67 & 0.61 & 0.27 & 1.04 & & & & \\
\hline Lowest value & -0.56 & -0.12 & -0.34 & -0.22 & & & & \\
\hline
\end{tabular}

Note: the index of comparability $(C I)$ for indicator variables was calculated according to Eqs (1)-(4).

\subsection{The descriptive statistics of the regression variables}

Table 4 reports the descriptive statistics for the variables used in the regression models. Overall, these statistics show a typical picture of a highly skewed data set for the size-related variables,

10 In the Ucieda Blanco and Garcia Osma (2004) study only net income and equity capital effects are reported. Due to the denominators' differences net income changes are not compared. 
audit fees, and fees for non-audit services. This calls for log transformations. However, in order to gain a better understanding of audit and non-audit fees, we report those fees here in millions of euros, although log transformations are used in the regressions. Table 4 reveals that the nonaudit fees vary from zero up to 3.4 million euros. Comparing the median values of audit fees to total assets, we find that approximately 1 euro of audit fee is paid for every 1,000 euros of total assets. However, for the non-audit fees, the median value is much lower since it is about half

TABLE 4. Descriptive statistics.

\begin{tabular}{|c|c|c|c|c|c|c|}
\hline & Year & Mean & Median & Std. Dev. & Minimum & Maximum \\
\hline \multirow[t]{2}{*}{$A U$ (million $€$ ) } & 2004 & 0.343 & 0.102 & 0.688 & 0.015 & 4.500 \\
\hline & 2005 & 0.346 & 0.126 & 0.546 & 0.017 & 2.900 \\
\hline \multirow[t]{2}{*}{$N A U($ million $€)$} & 2004 & 0.175 & 0.064 & 0.319 & $\mathbf{0}$ & 1.633 \\
\hline & 2005 & 0.207 & 0.059 & 0.457 & $\mathbf{0}$ & 3.400 \\
\hline \multirow[t]{2}{*}{ TAU (million $€)$} & 2004 & 0.518 & 0.162 & 0.982 & 0.015 & 6.000 \\
\hline & 2005 & 0.553 & 0.192 & 0.974 & 0.020 & 6.300 \\
\hline$A D J$ & 2004-2005 & 0.501 & 0.528 & 0.217 & $\mathbf{0}$ & 1 \\
\hline \multirow[t]{2}{*}{$S I Z E($ million $€)$} & 2004 & 532.501 & 109.527 & 1048.97 & 4.792 & 6486.00 \\
\hline & 2005 & 566.906 & 116.935 & 1080.83 & 5.240 & 6294.00 \\
\hline \multirow[t]{2}{*}{ INVREC } & 2004 & 0.378 & 0.344 & 0.170 & 0.020 & 0.780 \\
\hline & 2005 & 0.387 & 0.402 & 0.166 & 0.025 & 0.711 \\
\hline \multirow[t]{2}{*}{ SUBS (\#) } & 2004 & 26.055 & 12.000 & 32.369 & 2 & 189 \\
\hline & 2005 & 26.534 & 12.000 & 33.255 & 1 & 189 \\
\hline \multirow[t]{2}{*}{$R O E$} & 2004 & 0.114 & 0.138 & 0.219 & -0.692 & 0.686 \\
\hline & 2005 & 0.123 & 0.163 & 0.225 & -0.869 & 0.556 \\
\hline \multirow[t]{2}{*}{$M B$} & 2004 & 2.369 & 2.071 & 1.379 & 0.512 & 7.926 \\
\hline & 2005 & 2.595 & 2.230 & 1.472 & 0.5054 & 8.727 \\
\hline \multirow[t]{2}{*}{$B R$} & 2004 & 0.410 & 0.360 & 0.356 & -0.174 & 1.399 \\
\hline & 2005 & 0.447 & 0.384 & 0.328 & -0.211 & 1.288 \\
\hline \multirow[t]{2}{*}{ FLEV } & 2004 & 0.124 & 0.207 & 0.148 & $\mathbf{0}$ & 0.563 \\
\hline & 2005 & 0.212 & 0.211 & 0.154 & $\mathbf{0}$ & 0.619 \\
\hline \multirow[t]{2}{*}{$Q R$} & 2004 & 1.291 & 1.020 & 0.960 & 0.280 & 6.800 \\
\hline & 2005 & 1.206 & 1.030 & 0.844 & 0.230 & 6.560 \\
\hline \multirow[t]{2}{*}{ DISSUE } & 2004-2005 & 0.493 & $\mathbf{0}$ & 0.503 & $\mathbf{0}$ & 1 \\
\hline & 2005-2006 & 0.493 & $\mathbf{0}$ & 0.503 & $\mathbf{0}$ & 1 \\
\hline \multirow[t]{2}{*}{$P W C$} & 2004 & 0.397 & $\mathbf{0}$ & 0.493 & $\mathbf{0}$ & 1 \\
\hline & 2005 & 0.397 & $\mathbf{0}$ & 0.493 & $\mathbf{0}$ & 1 \\
\hline
\end{tabular}

Note: $A U$ is the audit fees, $N A U$ is the non-audit fees, TAU is the total audit fees $(T A U=A U$ fees + NAU fees), $A D J$ is the adjustments comparability score, SIZE is the total assets, INVREC is the ratio of the sum of inventories and accounts receivable to total assets, SUBS is the number of subsidiaries, ROE is return on equity, $M B$ is growth opportunities measured by the ratio of market value to book value of equity, $B R$ is the market risk measured by equity beta estimated by Sharpe's (1964) market model using daily stock and OMX25 index returns over a one-year period before the end of the fiscal year, FLEV is financial leverage measured by the debt to equity ratio, $Q R$ is liquidity measured by quick ratio (ratio of current assets less inventories to current liabilities), DISSUE is an indicatory variable which has a value of 1 if the company has issued equity or long term debt in either the current year or subsequent fiscal year (zero otherwise), $P W C$ is an indicatory variable which has a value of 1 when statutory auditing company is PricewaterhouseCoopers and zero otherwise. 
when compared to the audit fees. This suggests that provision of audit services may be a more important source of revenues for audit companies than provision of non-audit services. The fees also seem to be quite stable during the sample years. It should, however, be kept in mind that the composition of total audit fees $(T A U=A U+N A U)$ can vary greatly depending on, among other things, the auditee's structure. Categorically, income statement or balance sheet related issues may require more audit effort depending on the structure of a firm.

Table 4 also indicates that the adjustments comparability score $(A D /)$ ranges from zero to one. A value of one indicates that there is at least one company in which the IFRS adjustments have been an extreme case (four times ninth decile) for every indicator. Also, in the other variables there is a considerably large variation, so the data should be highly suitable for our proposed research questions.

\subsection{Regression results}

\subsubsection{Estimation results for audit and non-audit fees}

The objective of our study is to analyse whether statutory auditors' fees (audit fees, non-audit fees) are related to the magnitude of the IFRS adjustments of consolidated financial statements by using a sample of first-time IFRS users in an environment where the local GAAP (in this study Finnish accounting standards, FAS) deviates significantly from international accounting standards (IFRS). The mandatory transition from FAS to IFRS at the beginning of 2004 (transition date), stipulated by Regulation (1606/2002) of European Parliament and Council (2002), provides ideal conditions to analyse how this system-wide change affects audit and non-audit fees. In this section, the results based on audit and non-audit fees are presented. The robustness of the results is scrutinized by some sensitivity analyses which are provided at the end of the section.

Auditees' categorization of audit fees ${ }^{11}$ can be somewhat arbitrarily, and also intentionally, misclassified as non-audit fees within the audit fees (e.g. Hackenbrack and Knechel 1997). AU items comprise of fees due to statutory audit and are therefore well-specified. With the NAU fee content there could be more variations. It should contain the non-audit service fees of the incumbent auditor. We admit that the true recognition of audit and non-audit fees, and how they are affected by regulatory change, is challenging. ${ }^{12}$ Furthermore, in disclosures the total audit fees (audit and non-audit fees) are typically fees caused by the auditor that issues the audit report. Services for other audit firms are not necessarily reported and separated in audit fees disclosures

11 The fees paid to auditors are separated into audit and non-audit fees based on the auditee's own declaration in the notes of the financial statements. Our enquiries for the local Financial Supervision Authority (FIN-FSA) and for the Central Chamber of Commerce were not successful in terms of receiving statistics covering audit and non-audit fees and their development. During the study we gained understanding that, at least, some audit firms analyze AU and NAU fees solely for their internal purposes (confidential data).

12 An interview with a professional APA, (Pajamo 2009) Big 4 partner revealed that there are variations, though decreasingly so, how firms subject to audit register and disclose their auditing and non-auditing fees. 
(there are exceptions, e.g. Kesko Corporation reports both audit fees of the auditor and audit fees of other auditing firms). This can cause noise, at least in estimates in which fees are treated separately.

Another reason to aggregate audit fees and non-audit fees together comes from Elliot (SEC 2000) who posited that non-audit services may actually support audit performance due to knowledge obtained during the provision of such non-audit services. Thus, we first consider total fees paid to the auditors, i.e. summing audit and non-audit fees, take a logarithmic and run the regressions. Table 5 presents the results gained from explaining the total fees paid to the statutory audit company by the complexity of the IFRS transition and control variables. The model is employed first by pooling the years together and then separately for each year. Before discussing the results, the potential multicollinearity between independent variables is considered using variance inflation factors (VIF). Rawlings $(1988,277)$ suggests a variance inflation factor VIF $>10$ as a guideline for serious multicollinearity. The VIFs of the variables in our regressions are clearly below that threshold value - the highest VIF is 3.06. In other words, multicollinearity, at least of the sort recognized by VIF, does not bias our results.

Consistent with our predictions, the adjustments comparability score $(A D /)$ as a measure for transition complexity is positive. There are also indications that the parameter estimates deviate significantly from zero. When the pooled data is used, the significant $(p<0.05)$ parameter estimate for $A D J$ is clearly resulted. This is in line with the view that total fees paid to the auditors increase as the complexity of the IFRS transition increases. Also, control variables, if significant, quite frequently provide estimates consistent with prior findings. Finally, the values of adjusted $\mathrm{R}^{2}$ vary from $78.5 \%$ to $80.9 \%$. These values suggest that about $80 \%$ of the variability of the fees paid to statutory auditors is explained by the models presented here. The values are similar to those found in previous studies, which are typically in the range from $60 \%$ to $80 \%$ (Cobbin 2002, 72-74). The results seem to support the positive relation between the degree of IFRS adjustments and total fees.

When separate regressions are run for each sample year the results are significant at the $5 \%$ level. Partitioning the data into years does not change the main, year-specific, conclusions materially. The coefficients for $A D /$ remain about the same but their significance levels are somewhat lower (still significant at the $5 \%$ level). There can be several reasons for this. For example, it is possible that partitioning the data into shorter periods can understate the association; the factors which determine fees associated with the IFRS transition can somewhat artificially be divided into years, causing non-contemporaneous fee/IFRS transition-association. ${ }^{13}$ This can increase noise in the estimates.

13 This is recognized also by interviewed APA auditor (Pajamo 2009). Especially non-audit fees could be clustered to a certain year. 
TABLE 5. The regression results for total audit fees (TAU).

(Total audit fees $(T A U)=$ audit fees $(A U)+$ non-audit fees $(N A U))$

\begin{tabular}{|c|c|c|c|c|}
\hline \multirow[t]{2}{*}{ Independent variable } & \multirow[t]{2}{*}{ expected sign } & \multirow[t]{2}{*}{ Pooled data } & \multicolumn{2}{|c|}{ Year } \\
\hline & & & 2004 & 2005 \\
\hline Intercept & $?$ & $\begin{array}{l}-11.357 \\
(<0.0001)\end{array}$ & $\begin{array}{l}-11.163 \\
(<0.0001)\end{array}$ & $\begin{array}{l}-10.901 \\
(<0.0001)\end{array}$ \\
\hline$A D J$ & + & $\begin{array}{l}0.543 \\
(0.0045)\end{array}$ & $\begin{array}{l}0.532 \\
(0.0350)\end{array}$ & $\begin{array}{l}0.619 \\
(0.0223)\end{array}$ \\
\hline $\ln (S I Z E)$ & + & $\begin{array}{c}0.435 \\
(<0.0001)\end{array}$ & $\begin{array}{c}0.423 \\
(<0.0001)\end{array}$ & $\begin{array}{c}0.409 \\
(<0.0001)\end{array}$ \\
\hline INVREC & + & $\begin{array}{c}0.554 \\
(0.0325)\end{array}$ & $\begin{array}{c}0.493 \\
(0.1314)\end{array}$ & $\begin{array}{c}0.495 \\
(0.1170)\end{array}$ \\
\hline$S Q(S \cup B S)$ & + & $\begin{array}{c}0.194 \\
(<0.0001)\end{array}$ & $\begin{array}{c}0.213 \\
(<0.0001)\end{array}$ & $\begin{array}{c}0.178 \\
(<0.0001)\end{array}$ \\
\hline$R O E$ & - & $\begin{array}{l}-0.686 \\
(0.0047)\end{array}$ & $\begin{array}{l}-0.507 \\
(0.1171)\end{array}$ & $\begin{array}{l}-0.864 \\
(0.0010)\end{array}$ \\
\hline$M B$ & + & $\begin{array}{c}0.075 \\
(0.0045)\end{array}$ & $\begin{array}{l}0.061 \\
(0.0713)\end{array}$ & $\begin{array}{l}0.084 \\
(0.0138)\end{array}$ \\
\hline$B R$ & + & $\begin{array}{c}0.302 \\
(0.0186)\end{array}$ & $\begin{array}{c}0.192 \\
(0.1730)\end{array}$ & $\begin{array}{c}0.540 \\
(0.0068)\end{array}$ \\
\hline$F L E V$ & $?$ & $\begin{array}{l}-0.598 \\
(0.0653)\end{array}$ & $\begin{array}{l}-0.680 \\
(0.1439)\end{array}$ & $\begin{array}{l}-0.402 \\
(0.4101)\end{array}$ \\
\hline$Q R$ & - & $\begin{array}{l}0.079 \\
(0.1184)\end{array}$ & $\begin{array}{c}0.062 \\
(0.1332)\end{array}$ & $\begin{array}{l}0.122 \\
(0.1198)\end{array}$ \\
\hline DISSUE & + & $\begin{array}{l}-0.063 \\
(0.2443)\end{array}$ & $\begin{array}{l}0.020 \\
(0.4441)\end{array}$ & $\begin{array}{l}-0.206 \\
(0.0506)\end{array}$ \\
\hline$P W C$ & + & $\begin{array}{c}0.255 \\
(0.0055)\end{array}$ & $\begin{array}{c}0.265 \\
(0.0312)\end{array}$ & $\begin{array}{c}0.241 \\
(0.0393)\end{array}$ \\
\hline F-value & & $\begin{array}{l}\mathbf{5 5 . 8 9} \\
(<0.0001)\end{array}$ & $\begin{array}{l}24.94 \\
(<0.0001)\end{array}$ & $\begin{array}{c}28.63 \\
(<0.0001)\end{array}$ \\
\hline Adj. $R^{2}$ & & 0.806 & 0.7853 & 0.809 \\
\hline
\end{tabular}

$T A U=A U+N A U$. The sample includes Finnish listed companies which began using IFRS on a mandatory basis in 2005. The final sample consists of 146 observations from 73 companies. Definitions for variables are provided in section 3 and in Table 4 . The notations below the regression coefficients in parentheses are based on the one-tailed $p$-values for signed predictions (two-tailed $p$-values otherwise) adjusted for an unknown type of heteroscedasticity using White (1980).

It is possible that IFRS adjustments cause uneven consequences for the pricing of auditing and non-audit services. Separate regression models (Eqs 6 and 7) are employed in order to focus more closely on whether the association between IFRS adjustments and the total audit fees results from audit services and/or non-audit services. Table 6 presents the results gained from explaining the audit fees and non-audit fees by the complexity of the IFRS transition and control variables. 
TABLE 6. The regression results for each sample year.

\begin{tabular}{|c|c|c|c|c|c|}
\hline \multirow[t]{2}{*}{$\begin{array}{l}\text { Independent } \\
\text { variable }\end{array}$} & \multirow{2}{*}{$\begin{array}{l}\text { Expected sign } \\
\text { Model 6/ } \\
\text { Model } 7\end{array}$} & \multicolumn{2}{|c|}{$\begin{array}{l}\text { Model 6. Dependent variable: } \\
\qquad \ln (A U)\end{array}$} & \multicolumn{2}{|c|}{$\begin{array}{l}\text { Model 7. Dependent variable: } \\
\qquad \ln (A U)\end{array}$} \\
\hline & & Year $=2004$ & Year $=2005$ & Year $=2004$ & Year $=2005$ \\
\hline Intercept & $? / ?$ & $\begin{array}{l}-9.791 \\
(<0.0001)\end{array}$ & $\begin{array}{l}-11.116 \\
(<0.0001)\end{array}$ & $\begin{array}{l}-7.101 \\
(0.3179)\end{array}$ & $\begin{array}{l}-5.393 \\
(0.4454)\end{array}$ \\
\hline $\ln (N A U)$ & ?/. & $\begin{array}{l}0.103 \\
(0.0022)\end{array}$ & $\begin{array}{l}0.059 \\
(0.0801)\end{array}$ & & \\
\hline $\ln (A U)$ &.$/ ?$ & & & $\begin{array}{l}1.164 \\
(0.0031)\end{array}$ & $\begin{array}{l}0.768 \\
(0.0103)\end{array}$ \\
\hline$A D J$ & $+/+$ & $\begin{array}{l}-0.009 \\
(0.4889)\end{array}$ & $\begin{array}{l}0.120 \\
(0.3549)\end{array}$ & $\begin{array}{l}1.477 \\
(0.1525)\end{array}$ & $\begin{array}{l}3.196 \\
(0.0191)\end{array}$ \\
\hline $\ln (S I Z E)$ & $+/+$ & $\begin{array}{c}0.358 \\
(<0.0001)\end{array}$ & $\begin{array}{c}0.413 \\
(<0.0001)\end{array}$ & $\begin{array}{l}0.319 \\
(0.1571)\end{array}$ & $\begin{array}{l}0.212 \\
(0.2567)\end{array}$ \\
\hline INVREC & $+/+$ & $\begin{array}{l}1.315 \\
(0.0014)\end{array}$ & $\begin{array}{l}1.087 \\
(0.0094)\end{array}$ & $\begin{array}{l}-3.140 \\
(0.0313)\end{array}$ & $\begin{array}{l}-4.116 \\
(0.0137)\end{array}$ \\
\hline$S Q(S \cup B S)$ & $+/+$ & $\begin{array}{l}0.188 \\
(0.0001)\end{array}$ & $\begin{array}{c}0.168 \\
(<0.0001)\end{array}$ & $\begin{array}{l}-0.082 \\
(0.2141)\end{array}$ & $\begin{array}{l}0.095 \\
(0.2541)\end{array}$ \\
\hline$R O E$ & $-1-$ & $\begin{array}{l}-0.750 \\
(0.0250)\end{array}$ & $\begin{array}{l}-0.518 \\
(0.0896)\end{array}$ & $\begin{array}{l}0.343 \\
(0.3569)\end{array}$ & $\begin{array}{l}-1.816 \\
(0.0509)\end{array}$ \\
\hline$M B$ & $+/+$ & $\begin{array}{l}0.060 \\
(0.1201)\end{array}$ & $\begin{array}{l}0.061 \\
(0.0850)\end{array}$ & $\begin{array}{l}0.136 \\
(0.1966)\end{array}$ & $\begin{array}{l}-0.154 \\
(0.2631)\end{array}$ \\
\hline$B R$ & $+/+$ & $\begin{array}{l}0.113 \\
(0.2943)\end{array}$ & $\begin{array}{l}0.111 \\
(0.3182)\end{array}$ & $\begin{array}{l}-0.485 \\
(0.2179)\end{array}$ & $\begin{array}{l}0.717 \\
(0.1274)\end{array}$ \\
\hline$F L E V$ & $+/-$ & $\begin{array}{l}-0.575 \\
(0.0771)\end{array}$ & $\begin{array}{l}0.393 \\
(0.2071)\end{array}$ & $\begin{array}{l}-0.162 \\
(0.4516)\end{array}$ & $\begin{array}{l}-4.150 \\
(0.0109)\end{array}$ \\
\hline$Q R$ & $-/ ?$ & $\begin{array}{l}-0.081 \\
(0.0589)\end{array}$ & $\begin{array}{c}0.064 \\
(0.1861)\end{array}$ & $\begin{array}{l}0.596 \\
(0.0140)\end{array}$ & $\begin{array}{c}0.241 \\
(0.1374)\end{array}$ \\
\hline DISSUE &.$/+$ & & & $\begin{array}{l}0.622 \\
(0.0502)\end{array}$ & $\begin{array}{l}0.441 \\
(0.1110)\end{array}$ \\
\hline$P W C$ & $+/$ & $\begin{array}{c}0.292 \\
(0.0225)\end{array}$ & $\begin{array}{c}0.104 \\
(0.2186)\end{array}$ & & \\
\hline F-value & & $\begin{array}{l}28.14 \\
(<0.0001)\end{array}$ & $\begin{array}{l}25.67 \\
(<0.0001)\end{array}$ & 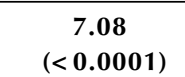 & $\begin{array}{c}7.37 \\
(<0.0001)\end{array}$ \\
\hline Adj. $R^{2}$ & & 0.806 & 0.790 & 0.481 & 0.493 \\
\hline
\end{tabular}

The sample includes Finnish listed companies which began using IFRS on a mandatory basis in 2005 . The final sample consists of 146 observations from 73 companies. Definitions for variables are provided in section 3 and in Table 4. The notations below the regression coefficients in parentheses are based on the one-tailed $p$-values for signed predictions (two-tailed $p$-values otherwise) adjusted for an unknown type of heteroscedasticity using White (1980).

The analyses suggest that the association between non-audit fees and the measure for IFRS transition complexity $(A D /)$ is closer than that for audit fees, being significant for the year 2005. The result is to some extent consistent with the second hypothesis that there is a positive relation between non-audit fees and the magnitude of the IFRS adjustments. Auditors have consulted firms (NAU) during their transition to IFRS. In general, auditing firms are in a better position to special- 
ize on consulting, non-audit, services and follow their own, tailored, pricing principles in this category of assignments. These NAU fees reflect first time start-up and learning costs. ${ }^{14}$ It is likely that those NAU costs will decrease, even quickly, when the IFRS reporting is adequately mastered by the firm itself.

The control variables, if significant, provide estimates fairly consistent with prior findings. The value of adjusted $\mathrm{R}^{2}$ varies from $48.1 \%$ to $80.6 \%$. In previous studies the non-audit fees have been less frequently used as independent variables compared to the audit fees. However, the results are in line with Whisenant et al. (2003).

Regarding the audit fees model (Model 6), $A D$ J does not gain statistical significance. The result is not consistent with the first hypothesis that there is a positive relation between audit fees and the degree of IFRS adjustments. This suggests that, based on the magnitude of the adjustments to consolidated financial statements, auditors do not charge higher audit fees during IFRS transition for the auditing of IFRS consolidated financial statements. In other words, auditors do not consider IFRS transition as causing significant changes to the components which determine their audit fees. This can be interpreted at least in three, complementary, ways. First, the risk that the IFRS financial statement is materially misstated is low. Second, knowledge spillover (or economic of scope) from non-audit services to auditing may exist. Third, tough competition prevented audit firms from translating audit-related IFRS transition costs into audit fees. ${ }^{15}$

Overall the analyses suggest that the non-audit fees, but not audit fees, are affected by the magnitude of the IFRS adjustments. In these kinds of major change situations auditors' involvement is increased - to some extent even permanently due to the more demanding IFRS requirements. Higher total audit costs may moderate over time to the extent that they reflect start-up or learning costs (Griffin et al. 2009). We believe that our focus of only two years (transition year and adoption year) supports the recognition of the relationship between the degree of IFRS adjustments and non-audit fees. Furthermore, it is likely that in our research setting, focusing on rapid transition (sample selection detailed in Table 1) from FAS to IFRS, non-audit fees capture start-up and learning costs. In line with that, it is likely that the increase in non-audit fees is mainly transitory in nature. Finally, it should also be borne in mind that during the FAS era there was a NAU type of consultation as well.

14 For example, according the interviewed APA auditor (Pajamo 2009), during the transition the consulting costs for mark-to-market accounting are in $N A U$, but later, when accounting decisions have been established regarding mark-to-market, those costs will appear in $A U$.

15 This is supported also by discussions with professional, authorized, auditors (Fredriksson 2009; Pajamo 2009). At and after the introduction of new corporate governance code (Corporate governance recommendation for listed companies 2003) there was audit supply competition among audit firms. Corporate governance code launched audit committees. Those committees evaluated actively corporations' audit function, especially auditing costs. APA proferssionals come to conclusion that auditing markets are highly competitive in Finland. Therefore core auditing services according the International Standards of Auditing (ISA) are likely to be fairly evenly priced throughout auditing firms (section 4 presents the institutional auditing framework in details). 
Regulatory and monitoring authorities should recognize the danger of decreased auditor independence in this kind of situation and, especially, establish ways to secure auditor independence. The strong role of audit committees supports this kind of development (Abbott et al. 2003; Miettinen 2008).

\subsubsection{The robustness of the results}

The robustness of the results is examined in three ways. First, instead of removing possible outliers, scaled rank transformations (see e.g. Kane and Meade 1998) are also used for independent variables. This method solves a number of methodological problems potentially associated with the ratios. For example, it requires no subjective choices regarding outlier cut off and/or deletion. Also, the number of observations remains unchanged, which is important if sample size is relatively small. The regression results after scaled rank transformation in independent variables remain qualitatively unaltered.

Secondly, the Hausman (1978) test of endogeneity is performed. The reason for considering simultaneity is the possibility that the association between non-audit fees and audit fees can cause a simultaneous-equation bias in the estimates. The employed Hausman test for endogeneity is based on comparing the OLS and two-stage least-square regression (2SLS) estimators ${ }^{16}$. The test did not reveal any endogeneity; however, since the exogenous variables are almost the same in Models 6 and 7 (only the last variables are different), there is not much information available for testing the endogeneity. Therefore some caution must be exercised when inferences are made.

Our third robustness check is related to our aggregate use of the adjustments comparability score metric $(A D /)$. As noted in section 3.1, our $A D J$-metric assumes the IFRS adjustments have a multiplicative effect on fees paid to the statutory auditor. In addition to using one overall combined measure of IFRS adjustments, we also analyze the potential differential effects of the different adjustments with the separate components of the overall $A D$ / comparability score metric. In practise, we run the regressions using four $D C I_{\text {scores }}\left(D C I_{E B I T}, D C I_{N I}, D C l_{E Q}\right.$ and $\left.D C I_{D E B T}\right)$ separately. In this way we should get insights into whether the effects of IFRS transitions are significant individually and thus receive more information about the key IFRS effects on fees paid to auditors. The results (not tabulated) show, when the pooled sample is used, that, $D C I_{E B I T}$, and $D C I_{E Q}$ are associated to total fees $(\mathrm{p}<0.05$, one-tailed test). When the model is employed separately for each year, the same variables are at least marginally $(p<0.10)$ significant for either 2004 or 2005. The analysis is also carried out using audit and non-audit fees as dependent variables. The results indicate that none of the $D C l$ scores are significantly related to audit fees. However, every $D C l$ score is at least marginally $(p<0.10)$ significant related to non-audit fees for either 2004

16 The basic code is http://support.sas.com/documentation/cdl/en/etsug/60372/HTML/default/etsug_model_sect050. $\mathrm{htm}$ 
or 2005. This suggests that each of our IFRS adjustment measures is individually involved with non-audit fees to at least some extent.

\section{SUMMARY}

This study focuses on a major accounting transition (from local GAAP to IFRS) and how it is associated with audit and non-audit fees. The study assumes that IFRS introduction is a one-off event for firms and so it is likely that it affects considerably the preparation of financial statements and work of auditing companies. The Finnish data were used as prior research findings suggested large differences between Finnish accounting standards (FAS) and the IFRS. The analysis indicates that almost half of the companies have had equity-scaled changes in equity capital and debt of more than five percent, whereas in net income a somewhat lower frequency was reconciled.

Consistent with our predictions, the results indicate that IFRS adjustments, as a measure of the disparity between FAS and IFRS, positively and significantly affect total audit fees paid to statutory auditors. Consequently, companies whose IFRS adjustments for income statements and balance sheets are relative small exhibit lower IFRS-related fees than corresponding firms that have relatively large IFRS adjustments. The results support our presumption that increased client complexity and risk associated with IFRS transition are associated with higher fees. Furthermore, our analyses of audit and non-audit fees show that disparity between FAS and IFRS is more closely related to non-audit fees than to audit fees. In other words, transition costs are mainly non-audit type rather than audit type reflecting primarily IFRS start-up and learning costs.

In general, this study adds to our knowledge on determination on audit and non-audit fees especially in a situation where audit risk and auditors' workload change (move from local GAAP to IFRS). Further research can focus more on the separate non-audit fee items. This would be possible because nowadays the content of the non-audit fees is required to be disclosed in more details. Finally, our measure for the complexity of IFRS transition $(A D /)$ was based on income statement and balance sheet figures. Further research could pay more attention to increased disclosure information as well (an essential part in the transition from FAS to IFRS).

The transition to IFRS from local GAAP has touched thousands of firms worldwide. The growing acceptance of IFRS increases the likelihood of new IFRS transitions (see e.g. SEC 2007). Thus, it is likely that new countries and firms outside the EU will also adopt IFRS in the future. We believe that our research topic and its findings have long lasting relevance especially for international readers, also creating potential large-scaled interest for auditing companies and their clients. Furthermore, country-specific mandatory transition to IFRS occurs only once. 


\section{REFERENCES}

ABBOTT, L. J., S. PARKER, G. F. PETERS, and K. RAGHUNANDAN. 2003. An empirical investigation of audit fees, nonaudit fees, and audit committees. Contemporary Accounting Research, 20, 215-234.

ABDEL-KHALIK, A. R. 1990. The jointness of audit fees and demand for MAS: A self-selection analysis, Contemporary Accounting Research, 6, 295-322.

ADAMS, C. A., P. WEeTMAN, E. A. E. JONES, and S. J. GRAY. 1999. Reducing the burden of US GAAP reconciliations by foreign countries listed in the United States: the key question of materiality, European Accounting Review, 8, 1-22.

AIRAKSINEN, M., P. PULKKINEN, and V. RASINAHO. 2007. Osakeyhtiölaki I [Corporate Law I], Helsinki: Talentum.

ALEXANDER, D. 2006. Legal certainty, European-ness and realpolitik. Accounting in Europe, 3, 65-80.

ANTLE, R., E. GORDON, G. NARAYANAMOORTHY, and L. ZHOU. 2006. The joint determination of audit fees, non-audit fees, and abnormal accruals. Review of Quantitative Finance and Accounting, 27, 235266.

ARENS, A. A., and J. K. LOEBBECKE. 1994. Auditing: an Integrated Approach (6th edn), London: Prentice Hall.

BALL, R. 2006. International Financial Reporting Standards (IFRS): pros and cons for investors. Accounting and Business Research, 36 (Special issue), 5-27.

BELL, T.B., W. R. LANDSMAN, and D. A. SHACKELFORD. 2001. Auditors' perceived business risk and audit fees: analysis and evidence. Journal of Accounting Research, 39, 35- 43.

CAMARAN, M. 2005. Audit fees and the large auditor premium in the Italian market, International Journal of Auditing, 9, 129-146.

CHUNG, S., AND R. NARASIMHAN. 2002. An international study of crosssectional variations in audit fees, International Journal of Auditing, 6, 79-91.

COBBIN, P. E. 2002. International dimensions of the audit fee determinants literature, International Journal of Auditing, 6, 53-77.

Committee of European Securities Regulators. 2003a. European regulation on the application of IFRS in 2005; Recommendation for additional guidance regarding the transition to IFRS. Ref: CERS/03-323e.

Committee of European Securities Regulators. 2003b. Standard no. 1 on financial information. enforcement on standards on financial information in Europe, March. http://www.europefesco.org

CORBIN J., and A. STRAUSS. 2008. Basics of Qualitative Research (3rd edn), Los Angeles: Sage.

Corporate governance recommendation for listed companies. 2003. A publication by the Helsinki Stock Exchange, the Central Chamber of Commerce of Finland, and Confederation of Finnish Industries. www. keskuskauppakamari.fi/kkk/julkaisuja/publications/en_GB/corporate_governance/

Corporate Governance Working Group. 2004. Corporate governance recommendation for listed companies. 2004. HEX Plc, Central Chamber of Commerce of Finland, Confederation of Finnish Industry and Employers. www.ecgi.org/codes/documents/recommendation_en_final.pdf

CRASWELL, A. T. 1999. Does the provision of non-audit services impair auditor independence? International Journal of Auditing, 3, 29-40.

DAVIS, L. R., D. N. RICCHIUTE, and G. TROMPETER. 1993. Audit effort, audit fees, and the provision of nonaudit services to audit clients, The Accounting Review, 68, 135-150.

DEBERG, C. L., S. E. KAPLAN, and K. PANY. 1991. An examination of some relationships between non-audit services and audit change, Accounting Horizons, 5, 17-28.

DING, Y., O.-K. HOPE, T. JEANJEAN, and H. STOLOWY. 2007. Differences between domestic accounting standards and IAS: Measurement, determinants and implications. Journal of Accounting and Public Policy 26:1, 1-38.

European Parliament and Council. 2002. Regulation (EC) No 1606/2002 of the European Parliament and of the Council of 19 July 2002 on the application of international accounting standards. http://europa.eu/ scadplus/leg/en/lvb/l26040.htm

EZZAMEL, M., D. R. GWILliAM, and K. M. HOLLAND. 1996. Some empirical evidence from publicly quoted UK companies on the relationship between the pricing of audit and non-audit services, Accounting and Business Research, 27:1, 3-16. 
Financial Supervision Authority. 2005. FIN-FSA's study on IFRS transition (in Finnish only, Selvitys listayhtiöiden IFRS-siirtymätiedottamisen laadusta ja siirtymän vaikutuksista. Working paper. Financial Supervision Authority. Market monitoring.

Financial Supervision Authority. 2006. Selvitys listayhtiöiden vuoden 2005 IFRS-tilinpäätöksistä. (in Finnish, press release in English Listed companies' IFRS financial statements still need developing http://www. fin-fsa.fi/Eng/FIN-FSA_News/Press_releases/9_2006.htm). Working paper. Financial Supervision Authority. Market monitoring.

FIRTH, M. 1997. The provision of non-audit services and the pricing of audit fees. Journal of Business Finance \& Accounting, 3\&4, 511-525.

FIRTH, M. 2002. Auditor-provided consultancy services and their association with audit fees and audit opinions. Journal of Business Finance \& Accounting, 5\&6, 661-693.

FRANCIS, J. R. and D. T. SIMON. 1987. A test of audit pricing in the small-client segment of the U.S. audit market. The Accounting Review, 62:1, 145-157.

FRANKEL, R. M., M. F. JOHNSON, and K.K. NELSON. 2002. The relation between auditors' fees for nonaudit services and earnings management. The Accounting Review, 77, 71-105.

FREDRIKSSON, A. 2009. Interview with the author on 14 Sep 2009.

GEIGER, M. A., and D. V. RAMA. 2003. Audit fees, non-audit fees and auditor reporting on stressed companies, Auditing: A Journal of Practice and Theory, 22:2, 53-69.

GLAUM, M., and D. L. STREET. 2003. Compliance with the disclosure requirements of Germany's New Market: IAS versus U.S. GAAP. Journal of International Financial Management and Accounting, 14:1, 64-74.

GRIFFIN, P. A., and D. H. LONT. 2007. An analysis of audit fees following the passage of Sarbanes-Oxley Asia-Pacific Journal of Accounting \& Economics, 14:2, 161-192

GRIFFIN, P. A., D. H. LONT, and Y. SUN. 2009. Governance regulatory changes, International Financial Reporting Standards adoption, and New Zealand audit and non-audit fees: empirical evidence. Accounting and Finance, 49:4, 697-724.

HACKENBRACK, K., and W. R. KNECHEL. 1997. Resource allocation decisions in audit engagements, Contemporary Accounting Research, 14, 481-499.

HAUSMAN, J. A. 1978. Specification tests in econometrics., Econometrica, 46, 1251-1271.

HALLER, A. 2002. Financial accounting developments in the European Union: past events and future prospects, European Accounting Review, 11, 153-190.

HAY, D. C., W. R. KNECHEL, and N. WONG. 2006. Audit fees: A meta-analysis of the effect of supply and demand attributes. Contemporary Accounting Research, 23, 141-191.

HODGDON, C., R. H. TONDKAR, A. ADHIKARI, and D. W. HARLESS. 2009. Compliance with International Financial Reporting Standards and auditor choice: New evidence on the importance of the statutory audit. The International Journal of Accounting, 44, 33-55.

HOOGENDOORN, M. 2006. International accounting regulation and IFRS implementation in Europe and beyond-experiences with first-time adoption in Europe, Accounting in Europe, 3, 23-26.

HOPE, O.-K. 2003. Disclosure practices, enforcement of accounting standards, and analysts' forecast accuracy: an international study. Journal of Accounting Research, 41, 235-272.

HORTON, J., and G. SERAFEIM. 2008. Market reaction to and valuation of IFRS reconciliation adjustments: first evidence from the UK. Working paper. Available at SSRN: http://ssrn.com/abstract=923582

HUNG, M., and K. R. SUBRAMANYAM. 2007. Financial statement effects of adopting international accounting standards: the case of Germany. Review of Accounting Studies, 12, 623-657.

ICAEW. 2004. Auditing implications of IFRS transition. Institute of Chartered Accountants in England and Wales. Technical releases, April 03/04. Audit and Assurance Faculty. London.

IFAC. 2008. Handbook of international auditing, assurance, and ethics pronouncements. International Federation of Accountants. http://www.ifac.org

JERMAKOWICZ, E. K., and S. GORNIK-TOMASZEWSKI. 2006. Implementing IFRS from the perspective of EU publicly traded companies. Journal of International Accounting, Auditing and Taxation, 15:2, 170196.

JOSHI, P. L., and H. AL-BASTAKI. 2000. Determinants of audit fees: evidence from the companies listed in Bahrain. International Journal of Auditing, 4, 129-138. 
KALLUNKI, J.-P., P. SAHLSTRÖM, AND M. ZERNI. 2007. Propensity to switch auditors and strictness of legal liability environment: The role of audit mispricing. International Journal of Auditing, 11, 165-185.

KANE, G. D, AND N. L. MEADE. 1998. Ratio analysis using rank transformation. Review of Quantitative Finance and Accounting, 10, 59-74.

KETTUNEN, P. 1993. Financial accounting and reporting in Finland. European Accounting Review, 2:3, 592-602.

KINNUNEN, J., J. NISKANEN, and E. KASANEN. 2000. To whom are IAS earnings informative? Domestic versus foreign shareholders' perspectives. The European Accounting Review, 9, 499-517.

KPMG. 2002. Implementing IAS. IAS compared with US GAAP and Finnish GAAP. KPMG International, Switzerland.

KPMG. 2003. Implementing IAS. Extract from IAS compared with US GAAP and Finnish GAAP.

KPMG International, Switzerland KPMG. 2006. IFRS-artikkelikokoelma. IFRSview. Audit, tax advisory. August. KPMG.

KPMG. 2009. IFRS Advisory Services. http://www.kpmg.fi/page.aspx?Section=1305\&ltem=2694.

LEUZ, C. 2003. IAS Versus U.S. GAAP: Information asymmetry-based evidence from Germany's new market. Journal of Accounting Research, 41:3, 445-472.

LEUZ, C., and R. E. VERRECCHIA. 2001. The economic consequences of increased disclosure. Journal of Accounting and Public Policy, 20, 129-153.

LEVITT, A. 2000. Renewing the covenant with investors, Speech at the New York University Center for Law and Business (May 10, available at http://www.sec.gov/news/speech/spch370.htm).

MARDEN, R. E., and K. S. BRACKNEY. 2009. Audit risk and IFRS. CPA Journal, 79:6, 32-36.

MIETTINEN, J. 2008. The effect of audit quality on the relationship between audit committee effectiveness and financial reporting quality. Acta Wasaensia no 197. Tampere: Tampereen yliopistopaino.

MIIHKINEN, A. 2008. Efficiency of authoritative disclosure recommendations: Evidence from IFRS transition disclosure in Finland. Journal of Financial Regulation and Compliance, 16:4, 384-413.

Ministry of Trade and Industry. 2003a. IAS supervision. Proposal of the MTI Working Group for the organisation of the supervision of the compliance of the financial information with the International Accounting Standards (IAS) in Finland. Ad hoc committee reports 7/2003 [English summary]. Helsinki: Edita.

Ministry of Trade and Industry. 2003b. Final report by the IAS working group. Ad hoc committee reports 9/2003 [English summary]. Helsinki: Edita.

MOIZER, P. 1997. Auditor reputation: The international empirical evidence, International Journal of Auditing, $1,61-74$

NIEMI, L. 2002. Do firms pay for audit risk? Evidence on risk premiums in audit fees after direct control for audit effort. International Journal of Auditing, 6, 37-51.

NIEMI, L. 2005. Audit effort and fees under concentrated client ownership: Evidence from four international audit firms, The International Journal of Accounting, 40, 303- 323.

NIKKINEN, J., and P. SAHLSTRÖM. 2005. Risk in audit pricing: the role of different dimensions of risk. Advances in International Accounting, 18, 141-151.

NOBES, C. W. 2006. Revenue recognition and EU endorsement of IFRS, Accounting in Europe, 3, 81-89.

O'KEEFE, T.B., D.A. SIMUNIC, and M.T. STEIN. 1994. The production of audit services: evidence from a major public accounting firm, Journal of Accounting Research, 32:2, 241-261.

PAJAMO, P. 2009. Interview with the author at the KPMG office on 2 Oct 2009 between 09.00-11.00.

PALMROSE, Z.-V. 1986. The effect of nonaudit services on the pricing of audit services: Further evidence Journal of Accounting Research, 24, 405-411.

PATEL, A., V. S. VARMA, and P. PRASAD. 2009. Provision of non-audit services, low balling, audit tenure and auditor type. ICFAI University Journal of Audit Practice, 6:1, 62-70.

PENMAN, S. 2001. Financial statement analysis and security valuation. Boston: McGraw-Hill.

PIRINEN, P. 2005. Economic and normative pressures as drivers for the adoption of international accounting standards in Finland since 1976. European Accounting Review, 14:1, 213-235.

PONG, C. M., and G. WHITTINGTON. 1994. The determinants of audit fees: some empirical models. Journal of Business Finance and Accounting, 21:8, 1071-1095. 
PRATT, J., and J. D. STICE. 1994. The effects of client characteristics on auditor litigation risk judgments, required audit evidence, and recommended audit fees, The Accounting Review, 69, 639-656.

PricewaterhouseCoopers. 2004a. International financial reporting standards, ready to take the plunge, (May). http://www.pwc.com/pl/eng/ins-sol/publ/2004/ifrs_survey06.pdf

PricewaterhouseCoopers. 2004b. Adopting IFRS, (June). http://www.pwc.com/ifrs

RAWLINGS, J. O. 1988. Applied regression analysis: a research tool. Belmont, CA: Wadsworth and Brooks.

REES, R. 1995. Financial analysis. $2^{\text {nd }}$ edition. Prentice Hall: Great Britain.

REYNOLDS, J.-K., D. E. DEIS, and J. R. FRANCIS. 2004. Professional service fees and auditor objectivity. Auditing: A Journal of Practice \& Theory, 23:1, 29-52.

RÄTY, P. 1992. Reforming Finnish accounting legislation. European Accounting Review, 1:2, 413-20.

SALMI, T. 1996. A comparative review of the Finnish Expenditure-Revenue accounting. Based on working paper 78-2. European Institute for Advanced Studies in Management, Brussels, Jan 1978. Rewritten for electronic publication in 1993. Technically revised in 1996. http://www.uwasa.fi/ ts/comp/comp.html

SCHADEWITZ, H., and M. VIERU. 2006. Relevance and sufficiency of pre-reporting: transition of Finnish small and medium-sized listed companies to IFRS. Working paper. Available at SSRN.

SEC. 2000. Hearing on auditor independence. September 21, 2000. http://www.sec.gov/rules/extra/audmin4. htm

SEC. 2007. SEC Takes Action to improve consistency of disclosure to U.S. investors in foreign companies. http://www.sec.gov/news/press/2007/2007-235.htm.

SHARMA, D. S., and J. SIDHU. 2001. Professionalism vs. commercialism: the association between non-audit services (NAS) and audit Independence, Journal of Business Finance \& Accounting, 5 \& 6, 595-629.

SHARPE, W. 1964. Capital asset prices: a theory of market equilibrium under conditions of risk, Journal of Finance 19, 425-442.

SIMUNIC, D. A. 1980. The pricing of audit services: Theory and evidence, Journal of Accounting Research, 18:1, 161-190.

SIMUNIC, D. A. 1984. Auditing, consulting, and auditor independence', Journal of Accounting Research, 22:2, 679-702.

SIMUNIC, D. A., and M. T. STEIN. 1996. The impact of litigation risk on audit pricing: A review of the economics and the evidence, Auditing: A Journal of Practice and Theory, 15, 120-134.

SOLOMON, I. 1990. Discussion of 'The jointness of audit fees and demand for MAS: a self-selection analysis", Contemporary Accounting Research, 6:1, 323-28.

STREET, D. L., S. J. GRAY, and S. M. BRYANT. 1999. Acceptance and observance of International Accounting Standards: An empirical study of companies claiming to comply with IASs. The International Journal of Accounting, 34:1, 11-48.

STREET, D. L., N. B. NICHOLS, and S. J. GRAY. 2000. Assessing the acceptability of international accounting standards in the US: An empirical study of the materiality of US GAAP reconciliations by non-US companies complying with IASC standards, The Journal of International Accounting, 35, 27-63.

STREET, D. L., and S. M. BRYANT. 2000. Disclosure level and compliance with IASs: A comparison of companies with and without U.S. listings and filings. The International Journal of Accounting, 35:3, 305-329.

TARCA, A. 2004. International convergence of accounting practices: Choosing between IAS and US GAAP. Journal of International Financial Management and Accounting, 15:1, 60-91.

TAYLOR, M. H., and D.T. SIMON. 1999. Determinants of audit fees: the importance of litigation, disclosure, and regulatory burdens in audit engagements in 20 countries, The International Journal of Accounting, 34, 375-388.

UCIEDA BLANCO, J. L., and B. GARCÍA OSMA. 2004. The comparability of international accounting standards and US GAAP: An empirical study of Form 20-F reconciliations, International Journal of Accounting, Auditing and Performance Evaluation, 1, 5-36.

WHISENANT, S., S. SANKARAGURUSWAMY, and K. RAGHUNANDAN. 2003. Evidence on the joint determination of audit and non-audit fees, Journal of Accounting Research, 41, 721-744.

WHITE, H. 1980. A heteroscedasticity-consistent covariance matrix estimator and a direct test for heteroscedasticity. Econometrica ,48, 817-838.

WU, J. S. 2008. Discussion of Will harmonizing accounting standards really harmonize accounting? Evidence from non-U.S. firms adopting U.S. GAAP, Journal of Accounting, Auditing and Finance, 23:2, 265-270. 